\title{
DIAGNOSIS PARTICULARITIES OF TRAUMATIC DIAPHRAGMATIC RUPTURES
}

\section{Roman Chirkov, Vladimir Murga ${ }^{\bowtie}$, Famil Babayev, Ivan Vakarchuk}

\author{
Department of Oncology, Surgery and Palliative Medicine \\ Tver State Medical University, Tver, Russia
}

Childtv@mail.ru

KEYW ORDS - trauma, rupture of the diaphragm, diagnosis, treatment, traumatic diaphragmatic hernia.

\section{NTRODUCTION}

Diaphragm rupture is one of the relatively rare and poorly studied type of injury, that causes complications and occurs in patients with blunt combined trauma of the chest and abdomen $[1,2]$. Rupture of the diaphragm is characterized by the severity of the clinical course, the difficulty of timely diagnosis, the complexity of treatment and high mortality $[1,2]$. The intense increase of trauma over the past decades makes the problem more relevant due to a noticeable tendency to increase the frequency of diaphragm rupture $[3,4]$. According to the literature sources, the number of ruptures of the diaphragm varies from 0,5 to $6,8 \%$ in the overall structure of blunt combined and multiple injuries of the chest and abdomen $[1,5]$.

Recognition of diaphragm rupture in the early stages after a trauma is difficult $[1,6]$. Some authors consider the diagnosis of victims to be untimely in more than $50 \%$ of cases, which determines an unfavorable prognosis $[3,4,6]$. It is also alarming that even during surgery for abdominal injuries diagnostic errors are made and the rupture of the diaphragm is detected during repeated surgery or autopsy [1].

Therefore, the aim of the work was to identify the features of clinical manifestations and modern concepts for diagnosing injuries of the diaphragm and its traumatic hernias.

\section{MATERIAL AND METHODS}

The analysis of the features of the clinical picture and diagnostic algorithms in 91 patients with diaphragm injury and 68 with traumatic diaphragmatic hernias was carried out. All patients were treated at the clinical bases of the Department of Oncology, Surgery and Palliative Medicine of Tver State Medical Uni- versity since 1964 . In most cases $(83,5 \%)$ among the victims were men. The median age was $37.2 \pm 1,7$ years.

\section{RESULTS AND DISCUSSION}

The mechanisms of injury were the following: in 66 car accident trauma $(61.5 \%)$, catatrauma $(20.9 \%)$, a blow to the abdomen (7.7\%), compression of the body between objects $(5.5 \%)$, penetrating injuries (4.4\%). The condition of most of the victims was of medium severity, due to the development of acute and massive blood loss, traumatic brain injury and the presence of bone fractures. Furthermore, the presence of alcohol intoxication significantly complicated the diagnosis of diaphragm injury.

During the physical examination of the chest in cases with large diaphragmatic hernias there were determined the lesion of the upper half of the chest on the side of the injury, weakening of the voice tremor, shortening of the percussion sound and in some patients the displacement of the mediastinum in the opposite direction. Weakened vesicular respiration was heard during auscultation. Peristaltic intestinal noises in the pleural cavity were detected in 42 patients.

$\mathrm{X}$-ray and ultrasound diagnostic methods were used. However in some cases the use of ultrasound was impossible due to large amount of subcutaneous fat or the presence of subcutaneous emphysema due to multiple rib fractures, which is often found in diaphragm lesions.

The overview $x$-ray of the thoracic cavity in the left pulmonary field reveals an additional thin-walled formation which contains gas and liquid. It is also necessary to pay attention to the condition of the diaphragm domes, their location and mobility. The presence of liquid in the colon is better detected on a lateral $x$-ray. Usually the abdominal organs stationed in the chest cavity cause compression hypoventilation of the lung, which is manifested by a decrease in its volume and the convergence of pulmonary vessels. Indirect symptoms also include displacement of the mediastinum, trachea and main bronchi to the opposite side. The appearance of several horizontal levels of fluid of small size on the background of pulmonary tissue indicates a movement of the intestine into the pleural cavity.

Clinical experience shows that the diagnosis of suspected traumatic diaphragmatic hernias is not difficult, especially under conditions of a specialized clinic. 
The analysis showed that the main causes of diagnostic errors were: rarity of this pathology; underestimation of anamnesis, which indicates injury of the chest or abdomen; refusal to use the radiological methods of diagnostics; insufficient knowledge of the clinical course of traumatic diaphragmatic hernias by doctors; incomplete examination of the thoracic and abdominal cavities.

Confirmation of the above can be the fact that the diagnosis was established correctly only in 2 of the 21 patients with strangulated traumatic diaphragmatic hernias.

\section{CONCLUSIONS}

To date, the problem of surgical treatment of diaphragm injury and its consequences remains extremely relevant. Early use of the $\mathrm{x}$-ray method of diagnosis and ultrasound will reduce the multifaceted complications of diaphragm injury.

Optimal preoperative and intraoperative diagnosis of diaphragm injuries and dynamic monitoring of the patient in the postoperative period to identify the cause of rupture or formation of traumatic hernia of the diaphragm are the basis for the full treatment of the considered cohort of victims.

\section{REFERENCES}

1. Aliev SA, Bayramov NIu, Aliev ES. Osobennosti diagnostiki I taktiki khirurgicheskogo lecheniia razryvov diafragmy pri zakrytoi sochetannoi travme grudi i zhivota. Vestnik khirurgii im. I.I. Grekova. 2014. T. 173 , № 4. Р. 66-72.

2. Ercan M, Aziret M, Karaman K, Bostancab B, Akoaylu M. Dual mesh repair for a large diaphragmatic hernia defect: An unusual case report. Int J Surg Case Rep 2016; 28: 266-269. DOI: 10.1016/j. ijscr.2016.10.015

3. Plekhanov A.N. Travmaticheskaia diafragmalnaia gryzha. Vestnik khirurgii im. I.I. Grekova. 2012. T. 171, № 5. Р. 107-110.

4. Toidze VV, Vasyukova EL, Kaschenko VA, AkiMOV VP, VoLKOV AM. Lecheniie gigantskoi diafragmalnoi gryzhi. Vestnik khirurgii im. I.I. Grekova. 2013. V. 172, № 6. P. 21-25.

5. Lim BL, Teo LT, Chiu MT, Asinas-Tan ML, Seow E. Traumatic diaphragmatic injuries: a retrospective review of the 12-year experience at a tertiary trauma centre. Singapore Med J 2016; 1-16. DOI: 10.11622/ smedj.2016185

6. Thiam O, Konate I, Gueye ML, Toure AO, SECK M, CISSE M. Traumatic diaphragmatic injuries: epidemiological, diagnostic and therapeutic aspects. Springer Plus 2016; 5: 1614. DOI: 10.1186/s40064016-3291-1 